Journal of International Affairs

Vol. 3, 84-102, 2020

Doi: https://doi.org/10.3126/joia.v3i1.29085

Department of International Relations and Diplomacy

Tribhuvan University, Kathmandu, Nepal

\title{
Nepal-India Relations: Beyond Realist and Liberal Theoretical Prisms
}

\author{
Karun Kishor Karki
}

Hari KC

\begin{abstract}
Taking, as a point of departure, the historical narratives that tout Nepal-India relations as based on mutual respect of each other's sovereignty, we provide a critical reflection upon the flaws of such a single uncritical discourse that not only risks the danger of creating stereotypes but also leaves it incomplete and misleading. Although many aspects of the Nepal-India relations indeed predate the origin of the modern nation-state, any historical discourse that downplays the realpolitik in these relations leaves the story untold about India being a hegemon interfering in Nepal's internal affairs and obstructing Nepal's social, economic and political progression. From a neocolonial lens, we provide snapshots of the ways and instances in which India has infringed upon Nepal's sovereignty and independence.
\end{abstract}

Key Words: Nepal-India relations; foreign policy; bilateral relations; border dispute; South Asia; grand narrative; realism; liberalism; neocolonialism; hegemony 


\section{Introduction}

Some images implanted into the consciousness of the Nepalese during their formative high school years are those of Nepal as the Shangri-La, characterized by the phrase 'sundar, shanta, bishal' (beautiful, peaceful, great), the land of the valiant Gurkhas, and the nation never colonised by foreign powers. History textbooks chime in, hailing the cordiality and co-existence inherent in Nepal-India relations that predated the origin of modern nation-states. Further, both Nepal and India are portrayed as places from where the most ancient oriental philosophies, Hinduism and Buddhism, originated and where the Nepali and the Hindi languages were born from the same Sanskrit roots. This narrative that most high school students learn depicts the present-day Nepal and India as once being a vast swathe of culturally integrated land and cited as the Bharat Khanda of the Veda and the Purana epics to drive the point home.

Upon reflection, it becomes clear that such discourses about the relations between the two countries are grossly misleading and risk a critical understanding of the other side of the story. Any single narrative can indeed pose a danger and leave a contested space. It creates stereotypes. The problem with stereotypes is not that they are untrue, but that they are incomplete (Adichie, 2009). An equally significant dimension of the Nepal-India relations has been that of a 'paradox' between closeness and detachment (Tripathi, 2019). This article critically zeroes in on the other side of the narrative that has remained completely ignored and eschewed in Nepal's school education system and in some political grand narratives. Given the direct influence of India over a wide spectrum of Nepal's sovereignty and independence, this article unearths the historically subdued narratives, albeit invisible and well-meaning they might sound at times, to argue that Nepal-India relations are indeed mired in Indian hegemony, not merely in its paternalism.

\section{Indian Policy in South Asia}

Scholars have observed that Indian foreign policy is guided by Nehruvian ideals and his daughter Indira Gandhi’s ‘hard realism’ (Malone, 2012; Muni, 2009). Nehru is perceived as an architect of independent India and the foreign policy, during his era, was to provide an overlay of democratic ambience (Muni, 2009). However, on the 'Kashmir question', his idea of secularism and strong anti-imperialist stance has further endorsed separatism. It is also argued that Bangladesh came into being as a result of the fight against internal colonialism in undivided Pakistan in 1971. Bloomfield (2014) writes,

Nehru was therefore caught on the horns of an ideational tri-lemma caused by 
conflicting commitments to the various aspects of what he believed should constitute India's identity. Unfortunately, South Asia still lives with his failure today (p. 160).

Chattopadhyay (2011) also critiques Nehru's broader vision of Asian unity and solidarity as being "based on India's internal needs and conditions, its history, traditions and way of life...to develop India economically" (p. 95). Moreover, the post-Nehruvian era witnessed the Indian foreign policy aimed towards its neighbouring countries through interest-based strategies that suit the changing global political milieu. For example, Indira Gandhi used the political channel to project Indian foreign policy (Chattopadhyay, 2011). During her era, Pakistan's territory was reduced in size and Sikkim was annexed to India. South Asian Association for Regional Cooperation (SAARC) was formed in 1985 a year after her assassination. India's foreign policy, centred on its national interests, promotes its proactive role to become a superpower or at least an unchallenged 'regional hegemon' in South Asia. Chattopadhyay (2011) provides the following three assumptions behind Indian foreign policy during the leaderships of Jawaharlal Nehru and his daughter:

a) India had to shoulder the role and responsibilities of the region; b) India would be the leader of anti-colonial struggles and would help to create a buffer of 'Third World' states; and c) India would collaborate with China to keep Asia free from superpower rivalry (p. 104).

Although India was expected to exorcize the colonial legacy following its independence from British colonialists in 1947, it continued the pre-colonial foreign policy in South Asia. Nehru's ideals and Indira Gandhi's realism have not disappeared from India's neighbourhood policy. Economic globalism and/or regionalism has significantly impacted Indian foreign policy towards its regional neighbours where India is operating as an interventionist. India is widely considered to be an emerging power today primarily due to its economic strength.

In the context of Nepal's internal policy making and foreign policy, the interference of India is perceived as hegemonic; and not through paternalism alone. In The Rising Nepal (n.d.), Narad Bharadwaj, a professor of history at Tribhuvan University, quotes a portion of a letter written by Vallabhbhai J. Patel - first deputy prime minister and one of the founding fathers of Republic of India - to Jawaharlal Nehru. In his letter (November 7, 1950), Patel writes,

In Nepal, like in Hyderabad, Indian nationals have been victims of inhuman treatment of the Rana regime. To stop that atrocity and anarchy, India should send its army in Nepal and take her under its control, eventually to make it yet another member of the Indian Federation, just like Kashmir and Hyderabad. 
Despite the Indian imperialistic maneuvers staged at various periods in history, the debates on Nepal-India bilateral relations during the autocratic Rana and Panchayat regimes were confined only among select political elites. Following the restoration of multi-party democracy in Nepal in 1990 after Jana Andolan, the irritants in Indo-Nepal relations began to be debated not only in public intellectual circles but also in the media, civil society and the general public. Similarly, the second political mass movement, popularly known as Jana Andolan II, ushered a federal democratic republican set up in Nepal leading to a massive restructuring of the state. The political transformations have created a free media that brought those debates on Nepal-India relations into the public discourse. However, the party leaderships have demonstrated their incompetence and immaturity numerous times in conducting the country’s foreign policy.

In the history of contemporary world politics hardly has any country gone through a series of political transformations similar to those in Nepal - from the autocratic Panchayat system to constitutional monarchy, the decade-long Maoist insurgency to the abolition of the Shah dynasty and then on to institutionalization of a federal republican system. Alongside the political transformations, Nepal has also been making impressive strides in multiple areas, such as the adoption of a constitution that has institutionalized secularism and inclusion and made significant developments on a number of social and economic fronts. Despite the fundamental and massive social and political upheavals that Nepal has witnessed over the last two decades, and a heightened level of political consciousness among the Nepalis, India has continued to embrace the same policy that looks at Nepal only through its security lens (Shah, 2017). More importantly, during and after sensitive political transitions in Nepal, India has claimed its share of the political spoils which has been evidenced through various interventionist, hegemonic activities in Nepal's internal affairs. The 2015 blockade that India imposed against Nepal for not being able to get that share can be taken as the latest episode in that series.

\section{Nepal's Geopolitical Location}

Geographically, Nepal which covers a total area of 147,516 square kilometers is situated between India and China, and has served admirably as a buffer zone between these two emerging powers of Asia (See Figure -1). Some scholars suggest that Nepal needs to get out of this buffer zone mindset to escape from the economic backwardness and political volatility it has been perennially facing (K. C. \& Bhattrai, 2018). To the north, Nepal shares its borders with Tibet Autonomous Region (TAR) of China and is separated in a number of places by the Himalayan mountains, including Mt. Everest. India surrounds Nepal from East, West and 
South. As shown in the map below, Nepal is a landlocked country, but in reality, it is 'Indialocked' as it shares an about 1,753 kilometers long border with India (Jha, 2010). Given the geopolitics of Nepal, the Nepal-India relations invariably come to the forefront of Nepal's foreign policy, although Sino-Nepal relations are of no less significance.

Any discourse on the Nepal-India relations would remain incomplete without reviewing the Indian encroachments of Nepali territory. There are about 71 areas of disputes including 26 places where India has encroached upon Nepal's borders (Zehra, 2020), and these disputed areas cover more than 60,000 hectares of land in 21 districts of Nepal (Paudyal, 2014). The major ones include Kalapani, Limpiyahura, Lipulek, Susta, Tanakpur and Mechi. In places, where the boundary between Nepal and India is marked by rivers that continuously change course. Similarly, the unavailability of old maps and documents to revise the demarcations has made the situation even harder to resolve (Subedi, 1994).

Politically meaningful is the silence that India has maintained on these issues while it keeps encroaching upon the disputed lands. Many scholars on Nepal-India relations observe that the treaties and agreements signed by the two countries on water resources, such as the Koshi and the Gandak agreements, were not in favour of Nepal (Jha, 2010; Subedi, 1994). This shows that India wants to confiscate Nepal's natural resources, including water resources. India has failed to launch an exemplary model of mutually beneficial projects between Nepal and India in water resource sharing.

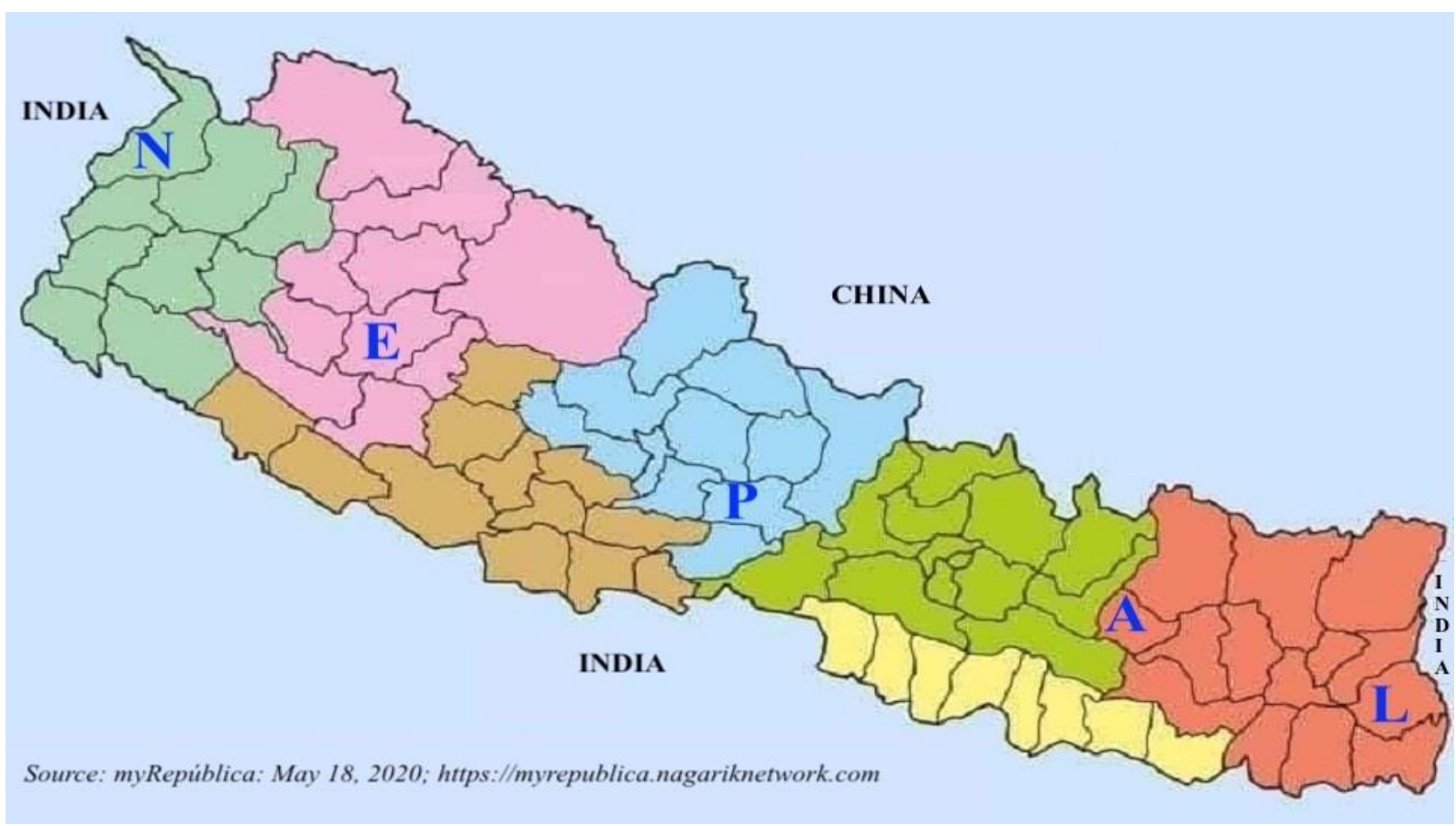

Figure 1: Geographical Location of Nepal 
On many occasions, the disappearance of the border-pillars has been witnessed - for instance, a large plot of land being used by the Nepali side in Jhapa District has become part of India when the missing pillars were replaced. Among the original pillars, which were erected as monuments of the Nepal-India border during the period of British colony in India, many have either disappeared or have been replaced with an intention of annexing Nepali land into India. Even at the grassroots level, Indian people have encroached by deforesting Nepali land. Based on eyewitness accounts, India has encroached into Nepali land in Shreeantu Guphapatal in the eastern district of Ilam. The encroachment has stirred violence and conflict in those areas. Although issues of border encroachment have been widely reported by journalists, and after Nepali parliamentarians visited the disputed areas, no further initiatives have been taken to resolve the problem. On the contrary, land encroachment activities have heightened.

Subedi (1994) argues that the map published by British India right after Sugauli Treaty (1816) clearly states that the old pillars are the official boundary markers between the two countries. Unfortunately, many of these pillars have been uprooted and gone missing. There has been hue and cry over the issue by Nepali people over the issue. Several diplomatic efforts initiated to solve them from the Nepali side have seen giant India always turning its deaf ear.

\section{Nepal-India Bilateral Relations}

Although Nepal never became a colony of Britain, many aspects of the Nepal-India relations were constituted during the British colonial era in India from the ideological plinth built on British colonial power. As quoted by Thapliyal (1998), addressing the Indian parliament on 6 December 1950, Jawahar Lal Nehru had remarked,

From time immemorial the Himalayas have provided us a magnificent frontier.

Of course, they are no longer as impassable as they used to be, but they are still fairly effective. We cannot allow the barrier to be penetrated, for it is also the principal barrier to India. Much as we stand for the independence of Nepal, we cannot allow anything to go wrong in Nepal or permit that barrier to be crossed or weakened, because that would be a risk to our own security.

The independence of India from British colony in 1947 was expected to usher a fresh start in Nepal-India relations built on the principles of equality, independence, sovereignty and mutual respect and benefit (Adhikari, 2018). Seldom have these principles been upheld by India, which constantly keeps a keen interest in having its sway over Nepal. It maintains the hegemony through interference in Nepal's internal affairs, including the political, diplomatic and even 
military.

Critiquing the Indian hegemonic interferences is not to downplay the unique friendship and cooperation between the two countries - the political and economic engagements and people-topeople relation anchored in culture, tradition, religion (Shah, 2017; Tripathi, 2019; Upreti, 2016). There has been a regular exchange of high-level visits and several bilateral institutional dialogues/interactions, including Nepal-India Joint Commission Meetings between the two countries. Such visits have helped promote goodwill, trust, and cooperation between two countries (MOFA, n.d.).

India has provided development assistance to Nepal, including building infrastructures at the grassroots level in the areas of education, health, water resources and security (MOFA, n.d.). In recent years, India has been assisting Nepal in the development of integrated check-posts on the Nepal-India border, e.g. in a) Jogbani-Biratnagar, b) Sunauli-Bhairahawa, c) Raxaul-Birganj, and d) Nepalganj Road-Nepalgunj (MOFA, n.d.). Similarly, water resource is another vital agenda of the bilateral relations because these rivers have the potential to become major sources of irrigation and power for both countries. India and Nepal have had a Power Exchange Agreement since 1971 for meeting the power requirements in both countries by taking advantage of each other's transmission infrastructure. 


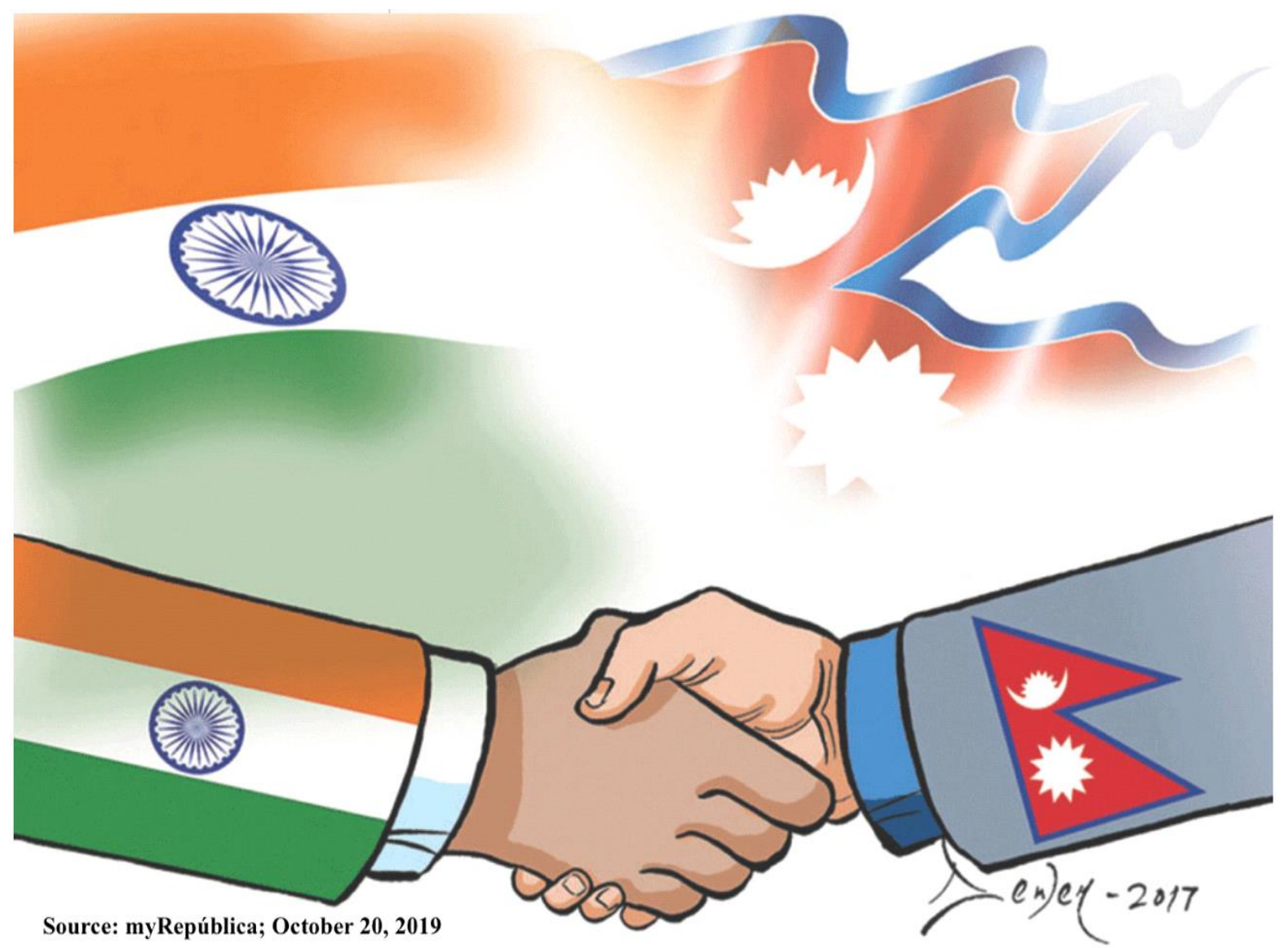

Figure 2: Depiction of Nepal-India Bilateral Relations

Another important bilateral cooperation is the defence sector. Both countries have institutionalized and established Joint Working Group on Border Management (JWG) and Border District Coordination Committees (BDCCs) to deal with each other's security concerns (MOFA. n. d.). Boundary Working Group (BWG) was established in 2014 to take over the technical works related to the Nepal-India boundary- such as construction, repair and restoration of boundary pillars and vigilance over encroachments of the no man's land on the border.

The bilateral agreement on 'trade, transit and investment' is a matter of utmost importance to both countries. India has been the largest trading partner of Nepal and there has been a substantial increase in the volume of bilateral trade over the years between the two countries. Over 552 large, intermediate and small-scale projects have been implemented across Nepal at an estimated cost of 77 billion Nepalese rupees with Indian assistance since 1951. As shown in the figure below, on 10 September 2019, the prime ministers of Nepal and India jointly inaugurated South Asia's first cross-border petroleum products pipeline, from Motihari in India to Amlekhgunj in Nepal, through a video conference. 
Narendra Modi @ @arendramodi·Sep 10,2019

A special day for India-Nepal friendship!

My friend, PM Oli and I jointly inaugurated South Asia's first crossborder petroleum products pipeline from Motihari in India to Amlekhgunj in Nepal.

You would be happy that this project has been completed much ahead of schedule.

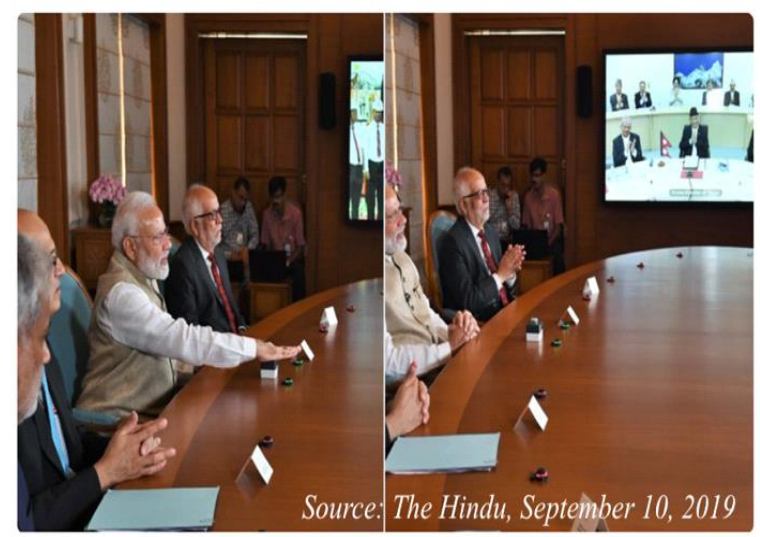

Narendra Modi

@narendramodi

Sharing the fruits of progress with friendly nations!

Motihari-Amlekhgunj pipeline will provide cleaner petroleum products at affordable costs to the people of Nepal.

I am glad that India and Nepal cooperation is scaling new
heights, for the mutual benefit of our people.

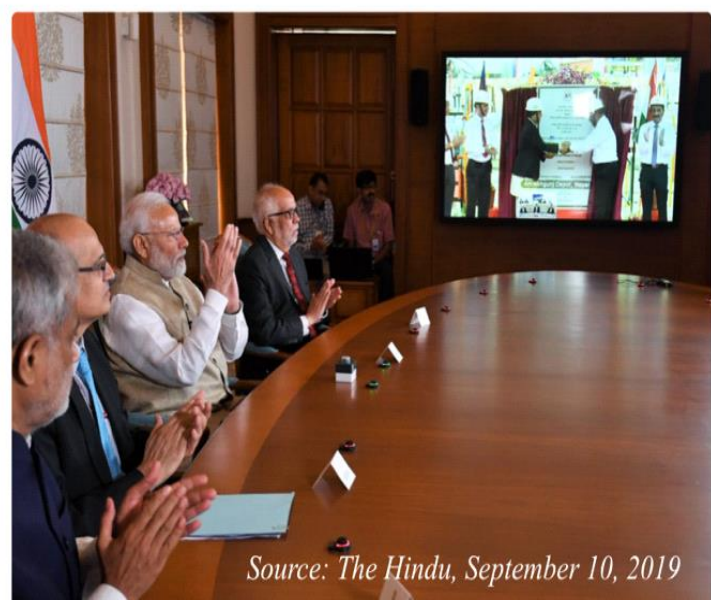

Figure 3: Narendra Modi's Tweet on Inauguration of Motihari - Amlekhgunj Pipeline (Special Correspondence, The Hindu, September 10, 2019)

The dominant discourse is that most treaties and agreements signed between Nepal and India, including Peace and Friendship Treaty of 1950, were unequal treaties, only serving Indian interests and aspirations. Because of such controversial and one-sided treaties, India has an influencing position in Nepal's politics, economy, culture, security, media and technology. Moreover, the historical context along with a long open border, socio-cultural homogeneity, huge economic and demographic exchanges between the two countries make it critically important to understand Nepal-India relations well.

The more than two-month long blockade imposed by India against Nepal in 2015 was a tragic and painful episode in Nepal-India relations - akin to the one in 1989 - 1990 when India punished Nepal for buying weapons from China in 1989 - that the new generation of Nepal experienced. India imposed an undeclared economic blockade by cutting the supply of medicine, fuel and other essential commodities to Nepal. In September 2015, Nepal's popularly elected Constituent Assembly passed a new constitution by an overwhelming majority (more than $90 \%$ of the CA members), but some socio-political groups protested against some aspects of the new constitution in the southern region of the country. India supported these disgruntled groups of the south because it was not in favour of Nepal's new constitution. When the Madesh- 
centric parties were flexing their muscles to protest against the new constitution, India's Foreign Secretary S. Jaishankar visited Nepal to pressure the Nepali political leadership and prevent its promulgation. This was when the Constituent Assembly was on the verge of promulgating it (Ghimire, 2015).

Ironically, India that boasts of being the largest democracy of the world refused to accept the Nepali people's mandate, and in retaliation, imposed the blockade. Such a direct interference in the internal affairs of an independent and sovereign country like Nepal can be argued as motivated by India's hegemonic arrogance. By imposing the economic blockade, India wanted Nepal to forcefully amend the new constitution. Even in the past, in 1989, when Nepal opted to purchase arms from China, India had pursued a similar tactic by blocking 13 of the 15 transit points on its border with Nepal to escalate its pressure (Garver, 1991; Nayak, 2016). Hence, India's relation with Nepal is not a paternalistic, but a hegemonic one exhibiting itself as the lawmaker of Nepal.

Experts of international relations say that the blockade was a violation of several international laws and conventions. It was a violation of Vienna Convention of 1965 (United Nations, 1965), which passed the Convention on Transit and Trade of Land-Locked States, allowing these nations to import goods from other countries without any hindrance. The blockade was the violation of UN Convention on the Law of the Sea of 1973 (United Nations, 1973), to which both Nepal and India are signatories, and one that allows all land-locked countries unhindered access to the sea. Further, it was the violation of their own Bilateral Trade Treaty which gives Nepal access to the sea via Indian territory. The blockade was also against Asian Highway Agreement (ESCAP, 2003) that Asian countries including Nepal and India have signed to connect their highways for regional trade. The blocked was against the South Asian Free Trade Area (SAFTA) agreement which was established to promote trade and business in the region. The SAFTA law does not allow any country to block other country's goods (https://commerce.gov.in/writereaddata/trade/safta.pdf).

Historically, India has continued its interventionist and hegemonic policies vis-à-vis its neighbours through its intelligence agencies, most notable Research and Analysis Wing (RAW). India is often blamed for playing a 'big brother' not only in Nepal but in other South Asian countries as well. With the world's second largest population and being a nuclear power, India has a strong military and fast-growing economy. The cartoon from India Today (April 30, 1984) cites Bhabani Sen Gupta, an Indian political scientist and foreign affairs expert, as saying: 


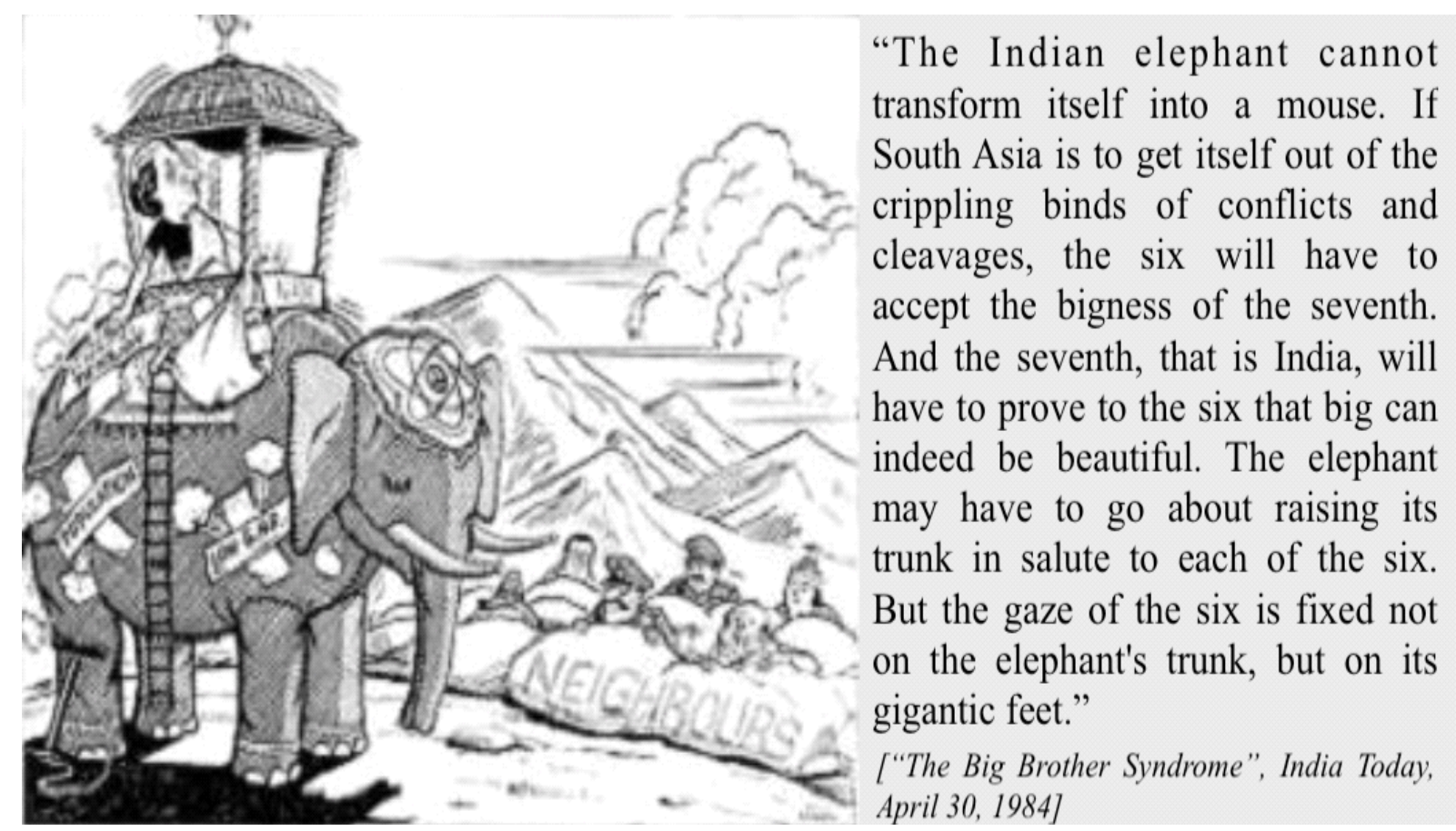

Figure 3: A Cartoon Showing India the Big Brother Syndrome

The cartoon demonstrates the perception that India's foreign policies are counterproductive for the regional harmony of South Asia. It has been argued that the foreign policy of India is deeply rooted in its colonial past and a continuation of Jawaharlal Nehru's desire to make India a 'superpower.'

\section{Beyond the Realist and Liberal Prisms}

Scrutinizing the Nepal-India relations from the past to the contemporary period, it can be argued that neither the realist nor the liberal theoretical approaches can capture their complex dynamics. Indian foreign policy aimed at Nepal is split between realism and liberalism and entails contradictions. Individuals are organized in states, each of which acts in a unitary ovary in pursuit of its own national interest (Mingst, 2004). The realist assumption is that the state is the key actor in international politics, and that relations among states are the core of actual international relations. Realists consider states to be single units and actors in international politics, and these actors act only according to self-interest and pursuit of power. Such an approach does not see any room for any abstract moral discourse in the relations between states, since "morality can only be relative, not universal" (Carr, 1971). To the contrary, the liberal approach to inter-state relations emphasizes on ideals and cooperation, and more importantly on what Carr (1971) calls the doctrine of the harmony of interests.

At this juncture it becomes imperative to bring in the ideological underpinnings of political 
realism and neo-colonialism to further explore the bilateral relationship. Some political scientists and/or theorists argue that political realism encompasses approaches that give more autonomy to distinctively different political thoughts (Galston, 2010; Williams, 2005). The authors suggest that the sovereignty of the political domain is drilled through the exercise of judgement, which is destabilized by economic, legal, military and moral principles. Galston (2010) is of the opinion that in political realism "appropriate standards of evaluation arise from within politics rather than from external moral standard" (p. 388). These ideological bedrocks suggest that it is fundamental for a realist to take into consideration the institutions within which conflict is mediated and contained. Galston (2010) further states, "realists see political conflict as ubiquitous, perennial, ineradicable, and they regard political moralists as being far too sanguine about the possibility of achieving either normative or practical consensus" (p. 396).

However, this realists' position can be contested when critically observing the Nepal-India relations. Given the Indian hegemony in Nepal's internal political affairs, unequal treaties, territorial encroachment and military (i.e. Border Security Force) activities along the border and control over its natural resources, this suggests a continuation of colonialism, but in a new formoften referred to as neocolonialism. India, itself once under colonial rule, has now taken over this role. Evidence suggests that India seldom appreciated any move from Nepal to move close to China. It is discernible that India is trying to impose its say in Nepal. Referring to India's diplomatic policies towards Nepal, Pande (2011) states,

Indian leaders and strategists treat Nepal as falling under India's sphere of influence-India's backyard - and are suspicious of any warming of ties between China and Nepal. Nepal is India's sole buffer with China, especially after Tibet was absorbed by China during the 1950s.

India can be said to have a direct influence on the internal and external policies of Nepal because of its economic leverage. Nepal, being an "India-locked" country, has to depend on transit access through India for international trade. Nepal-India trade and transit began to be regulated through Nepal - India- Treaty of Trade and Transit, which was signed in 1960, by replacing Trade and Commerce Treaty of 1950. Later, separate treaties were signed for transit and trade. These treaties have been renewed periodically. The transit treaty was last renewed in January 5, 2013 for a period of seven years. Similarly, in 2004, Rail Services Agreement was signed for Nepal's transit trade, thus allowing movement of goods to and from third countries, and from India, using Indian railway containers. Yet, another transit agreement is a trilateral transit understanding between Bangladesh, India and Nepal regulating the overland trade 
between Nepal and Bangladesh via India. However, there are a number of issues related to movement of transit cargo to/from Indian ports arising out of constraints in the existing treaty.

These issues are mostly associated with India's unnecessary regulation in terms of documentation requirements, transshipment procedures, sensitive items, arbitrary bank guarantees and poor transit infrastructure. With regards to trade and transit agreements, India has a keen desire to have a single treaty governing both trade and transit, as had been the case before 1978, while Nepal wants two separate treaties, one dealing with trade and the other with transit. As Shakoor (1989) argues, a single treaty covering both trade and transit can "jeopardize Nepal's freedom of foreign trade and make it subservient to Indian wishes" (p.68). This gives ample evidence that India is imposing its neo-colonial hegemony in Nepal.

Antonio Gramsci (1891-1937) coined the term 'hegemony' to refer to a distinct social relation within a country, i.e. between different social classes in society. The Gramscian notion of hegemony is useful to examine how a so-called powerful country, such as India, exercises its domination over other smaller countries, like Nepal, in its national and institutional sovereignty. According to Shah (2018), sovereignty is the "final and absolute political authority in the political community, and no final and absolute authority exists elsewhere" (p. 19). More specifically, the hegemony discussed here is explained more clearly by others. Warner (2006), defines it as "the leadership by a single stronger partner of other less strong, but still autonomous partners, undertaken for the mutual benefit of all parties concerned" (p. 3). Wallerstein (1983) conceptualizes the term 'hegemony' from a global perspective. The author argues that, when a state is superior in military, economic, political and cultural power, it sets the economic rules in a capitalist world and maintains it through mobilization of its own forces and cooperating peripheral elites. Goldstein (1988) defines the term hegemony as "being able to dictate, or at least dominate, the rules and arrangements by which international relations, political and economic, are conducted" (p. 23).

India is widely perceived to have dominance and hegemonic aspiration in Nepal through ideological or institutional means. India as a hegemon exercises its foreign policy through its economic and military power for the neocolonial purpose of perpetuating political dominance over Nepal. In the colonial period, the colonialists developed a certain kind of state system in their colonies to keep the economy oriented to meet their empire's interests. The narrative that Nepal has its own political system, its own economy and its own control over its natural resources thus comes into question. 
A country that has never been colonized can also become a neo-colony, which is independent in theory, but in reality, its economic system and political policy are directly under the influence of an external power. An example of a neo-colony is that it is coerced to carry out economic transactions and trade with the imperialist power, instead of enjoying the right of trading commodities in the international markets. In such a situation, the neo-colony is deprived of its freedom to pave the future for itself. The actions and effects of certain remnant features and agents of the colonial era can be found in a given society long after the empire has gone out. Post-colonial studies have shown extensively that despite achieving independence, the influences of colonialism and its agents are still very much present in the lives of most former colonies.

To what extent is Nepal an independent and sovereign country? Are the Nepalis citizens of an independent and free nation? Unlike what W.H. Auden who in 'An Unknown Citizen' says that the '[q]uestion remains absurd', in this context the answer remains absurd. When such questions are raised, some scholars deem them to reflect a 'fear psychosis' and the 'small state complexities' prevailing among the Kathmandu elites (Upreti, 2016). And, it is this fear psychosis that has paralyzed the Indian establishment in that when Nepal develops deeper relations with China, India considers it as a pressure tactic.

Nepal's geostrategic position sometimes overrides the basic assumptions of the established theories. Nepal has been struggling for its survival since the very beginning of its unification. The signing of a tripartite agreement compelling Nepal to provide the British and Indian armies with Gurkha soldiers to fight their wars, the peace and friendship treaty of 1950 with independent India, an extradition treaty with India in 1953 etc. have all given room for India to legitimately use its hegemonic designs over Nepal (K.C. 2072).

Following a fiasco of the Modi government in its attempt to coerce Nepal not to promulgate the constitution and the blockade it imposed to punish defiance, India has changed its tactics. Instead of directly coercing, India is showing its willingness to engage with Nepal on issues and concerns of Nepal, while at the same time dillydallying with any concrete outcomes. There is a disjuncture between intent and words. Even in bilateral development projects, such as hydro agreements between the two countries, India has failed to deliver on its commitments in time, and this has created distrust in Nepal over India's intent to implement the Mahakali Treaty by commencing construction of the Pancheswar dam project under the treaty. 
The structures in Nepal-India bilateral relations, in the form of unequal treaties and agreements, give an upper hand to India. Nepal's political leadership, as an actor in the relations, should be able to assert its agency. Structures "allocate differential capacities, and typically differential advantages, to different positions" and "shape self-understanding and subjective interests" (Barnett \& Duvall 2005, 53). The effects of structures are not unidirectional; agents-even relatively weak ones-replicate and perhaps alter structures. The dominant and the dominated are engaged in mutually co-constitutive relations, and the agency of the weaker state can alter the oppressive and unjust political structures. A proactive and agentic political leadership in Nepal can pressure India to revise the past bilateral agreements, which have proved to be detrimental to the nation's sovereignty, international dignity and degraded its ability to pursue the national interest. Constitution of Federal Republic of Nepal clearly states the government's commitment to pursue the review of treaties concluded in the past and make treaties and agreements based on equality and mutual interest (Article 5,1). It says that the state shall direct its international relations towards enhancing the dignity of the nation in the world community by maintaining international relations on the basis of sovereign equality, while safeguarding its freedom, sovereignty, territorial integrity and independence. In practice, however, there is a trend of changing foreign policy tilt with every change in the government in general and leader in particular. This trend has persisted in Nepal's foreign policy making for a long time.

In the contemporary multipolar world order, as Indian External Affairs Minister S. Jaishankar has stressed, world politics will witness the proliferation of 'frenemies', which refers to a political phenomenon where traditional allies compete with each other while the adversaries are compelled to stand together for a common cause (Jaishankar, October 1, 2019). The growing trade relations between India and China can be taken as evidence. In such a state of world affairs, Nepal is neither a buffer state as it used to be, nor would it be prudent to ally with any of our neighbours. The initiative taken by Nepal to form Eminent Persons Group (EPG) comprising foreign policy experts from Nepal and India can be taken as a laudable act. Following the meeting between Prime Minister K.P. Oli and Prime Minister Narendra Modi on 20 February 2016, the group was constituted with a mandate to review the Nepal-India relations, including 1950 Treaty of Peace and Friendship, in the spirit of the changed context. The ninth EPG meeting that concluded in Kathmandu prepared a single joint report and presented it to the respective governments. However, the Indian government has been shying away from receiving the report so far. 
Discarding the neocolonial hegemonic foreign policy, there is a need for India to review its foreign policy towards its South Asian neighbours, including Nepal. In the context of Nepal, India should be - not only in words but also in action with all intents and purposes - prepared to redefine the bilateral relations in the spirit of the changed context. Due to its own internal politics, India might naturally have security concerns in the same way China does, and Nepal should be vigilant to address any security concerns of our neighbours. For example, problems arising from the open border, like circulation of fake currency, increment in criminal activities, terrorist attacks, illegal trade, drug and human trafficking, etc., always create tension between the two countries. Equally important is that India should stop suspecting at Nepal's intention to expand its bilateral ties with China. India is not happy with Chinese investment in infrastructure and energy in Nepal. Such concerns are problematic. The security concern is one thing, but securitization of even legitimate development aspirations of Nepal is something else. Hagerty (1991) says,

Although it was never enunciated explicitly or officially, successive Indian governments have systematically pursued an active policy of denial in South Asia similar to that applied to the Western Hemisphere by the United States in the 19 th century (p. 363).

\section{Conclusion}

Neither the realist nor the liberal approach encompasses the entire gamut of Nepal-India relations. Only the neocolonial theoretical lens allows us to uncover those unmapped aspects of the Indian hegemony that have remained subdued. This provides snapshots of the ways and instances in which India has infringed upon Nepal's sovereignty and independence, and how Nepal-India relations are mired in the quicksand of Indian hegemony.

Many aspects of the Nepal-India relations are indeed unique, and these relations are not just confined to state-to-state relationship. These are connections that cut across the grassroots people. Further, the social, religious and cultural ties between the two countries and their peoples have existed since time immemorial. However, the relations between Nepal and India have always been fraught with a paradox (Saran, 2017). Although India was expected to exorcize the colonial legacy in the aftermath of independence from British colonization in 1947, it continued the pre-independence policy in its foreign policy approach regarding Nepal. The realpolitik is replete with India's hegemonic role in Nepal to the point that many times it has stood in the way of Nepal's accomplishments. 
India's policy needs to be informed by the changes occurring in the societies and politics in the neighborhood. It needs to be flexible enough to incorporate such changes. Despite all the changes in Nepal's internal politics, India has continued to adopt the same policy of looking only through the lens of its security (Shah, 2017). This should change in the positive direction to capitalize on the uniqueness of the relations. Morarji Desai, while visiting Nepal, had highlighted the uniqueness of the Nepal-India relationship - "No textbook on international relations contains an exact parallel to the pattern of relations which exist between our two sovereign nations'. Now, capitalize on that.

Karun Kishor Karki, PhD, (karunkarki@gmail.com)Assistant Professor, School of Social Work and Human Services, The University of the Fraser Valley, Canada

Hari KC, Doctoral Candidate, Global Governance, Balsillie School of International Affairs, Canada,E-mail: hkc@balsillieschool.ca

\section{References}

Adhikari, Dhruba. R. 2018. A Small State between Two Major Powers: Nepal's Foreign Policy Since 1816. Journal of International Affairs, 2:1, 43-74.

Adichie, Chimamanda. N. 2009. The Danger of a Singly Story. Accessed on March 30, 2020 https://www.ted.com/talks/chimamanda_adichie_the_danger_of_a_single_story/transcri pt?language $=$ en.

Barnett, Michael, and Raymond Duvall. 2005. Power in International Politics. International Organization 59:1, 39-75.

Bharadwaj, Narad. n.d. Why Anti-Indian Sentiment Grows in Nepal? Accessed on March 30, 2020 http://therisingnepal.org.np/news/8561

Bloomfield, Alan. 2014. Review of India in South Asia: Domestic Identity Politics and Foreign Policy from Nehru to the BJP, 2013 by Sinderpal Singh, Oxon: Routledge.

Carr, Edward. H. 1971. The Twenty Years' Crisis, 1919-1939: An Introduction to the Study of International Relations ( $2^{\text {nd }}$ Ed.). London: Macmillan.

Chattopadhyay, Pratip. 2011. The Politics of India's Neighbourhood Policy in South Asia. South Asia Survey, 18:1, 93-108

Economic and Social Commission for Asia and the Pacific (ESCAP). 2003. Asian Highway Network. Accessed on April 4, 2020 https://www.unescap.org/our-work/transport/asianhighway/about

Galston, William A. 2010. Realism in Political Theory. European Journal of Political Theory, 9:4, 385-411.

Garver, John. W. 1991. China-India Rivalry in Nepal: The Clash over Chinese Arms Sales. Asian Survey, 31:10, 956-975.

Ghimire, Yubaraj. 2015. Constitution Promulgation: Indian Foreign Secretary Meets Senior Leaders in Nepal. The Indian Express, September 19. Access on March 31, 2020 https://indianexpress.com/article/world/neighbours/constitution-promulgation-indianforeign-secretary-meets-senior-leaders-in-nepal/ 
Goldestein, Joshua, S. 1988. Long Cycle: Prosperity and War in the Modern Age. New Heaven: Yale University Press.

Gupta, Bhabani. S. 1984. The Big Brother Syndrome. India Today, April 30. Accessed on March 30, 2020 https://www.indiatoday.in/magazine/guest-column/story/19840430tamil-sinhala-conflict-is-not-india-creation-803002-1984-04-30.

Hagerty, Devin. 1991. India's Regional Security Doctrine. Asian Survey 31: 4, 351-363.

Jha, Hari. B. 2010. Nepal's Border Relations with India and China. Accessed on March 30, 2020 http://srch.slav.hokudai.ac.jp/publictn/eurasia_border_review/Vol41/V4N104J.pdf.

K.C. Khadga \& Bhattrai, Gaurav. 2018. Nepal's Search for Prosperity through Transit Diplomacy. Journal of International Affairs, 2:1, 75-96.

K.C. Surendra. 2072 B.S. Nepalko Bharat Niti Tatha Sandhi-Samjhautaharu in Nepal-Bharat Ra Chin Sandhi Samikshyatmak Vivechana. Kathmandu: Madhuvan Prakashan.

Malone, David. M. 2012. Does the Elephant Dance?: Contemporary Indian Foreign Policy. Oxford University Press.

MOFA. n. d. Nepal-India Relations. Government of Nepal Ministry of Foreign Affairs. Accessed on April 4, 2020 https://mofa.gov.np/nepal-india-relations/

Muni, S. D. 2009. India's Foreign Policy: The Democracy Dimension: with Special Reference to Neighbours. Delhi Foundation Books.

Mingst, Karen A. 2004. Essentials of International Relations ( $3^{\text {rd }}$ Ed.). New York: Norton.

Nayak, Nihar. R. 2016. Landlocked and transit developing countries: Nepal's transit route negotiations with India. Strategic Analysis, 40:2, 101-121.

Pande, Aparna. 2011. India's Nepal Policy. Accessed on March 31, 2020 from https://www.hudson.org/research/7615-india-s-nepal-policy-

Paudyal, Gynendra. 2014. Border Dispute between Nepal and India. Researcher: A Research Journal of Culture and Society, 1:2, 35-48.

Shah, Apkeshya. 2018. Shades of Sovereignty: Understanding Sovereignty in International Politics. Journal of International Affairs, 2:1, 19-42.

Shah, Shabaz. 2017. Indo-Nepal Relations: A Bilateral Paradox. IUP Journal of International Relations, 11:4, 28-48.

Saran, Shyam. 2017. How India Sees the World: Kautilya to the 21st Century. New Delhi: Juggernaut Books.

Shakoor, Farzana. 1989. Indo-Nepal Dispute. Pakistan Horizon, 42:3/4, 68-80. Accessed on April 7, 2020 https://www.jstor.org

Special Correspondent. India, Nepal Inaugurate Motihari-Amlekhganj Oil Pipeline. The Hindu, September 10, 2019. Assessed on April 4, 2020 https://www.thehindu.com/news/national/india-nepal-inaugurate-motihari-amlekhgunjoil-pipeline/article29382367.ece

Subedi, Surya. P. 1994. India-Nepal Security Relations and the 1950 Treaty: Time for New Perspectives. Asian Survey, 34:4, 273-284.

Thapliyal, Sangeeta. 1998. Mutual Security: The Case of India-Nepal. New Delhi: Lancer Publisher.

The Constitution of Nepal. 2072 B.S. Government of Nepal, Ministry of Law, Justice, Constituent Assembly and Parliamentary Affairs, Law Book Management Committee.

Tripathi, Dhananjya. 2019. Influence of Borders on Bilateral Ties in South Asia: A Study of 
Contemporary India-Nepal Relations. International Studies, 2:3, 186-200.

United Nations. 1965. Convention on Transit Trade of Land-locked States. United Nations,

$\begin{array}{llll}\text { Treaty Series. } & \text { Accessed } & \text { April } & 420\end{array}$ https://treaties.un.org/doc/Publication/MTDSG/Volume\%20I/Chapter\%20X/X-3.en.pdf

United Nations. 1973. United Nations Convention on the Law of the Sea. Accessed on April 4, $2020 \mathrm{https}: / / \mathrm{www}$. slideshare.net/AprilHibbard/united-nations-convention-on-law-of-thesea-1973

Upreti, B C. 2016. India-Nepal Relations: Complexities, Misperceptions and Irritants. Indian Foreign Affairs Journal, 11:2, 107-113.

Wallerstein, Immanuel. 1983. The three Instances of Hegemony in the History of the Capitalist World Economy. International Journal of Comparative Sociology, 24:1-2, 100-108.

Warner, Jeroen. 2006. Hegemony and the Nature of Order, Disaster Studies Group: Wageningen University \& Research, Accessed on March 30, 2020 https://lwrg.files.wordpress.com/2014/12/warner-hegemony-theory.pdf

Williams, Michael C. 2005. The Realist Tradition and the Limit of International Relations, Cambridge: Cambridge University Press.

Zehra, Ishaal. 2020. India's Infringement over Nepal Border Area. Global Research, January 02, 2020. Accessed on April 4, 2020 https://www.globalresearch.ca/indianinfringement-nepal-border-area/5699368 